\title{
Integrated Weed Management in Common Bean (Phaseolus vulgaris L.) at Wolaita Sodo, Southern Ethiopia
}

\author{
TOFIK ABDULKADIR YIMAMU \\ Lecturer in Wolaita Soddo Agricultural TVET College, South Nations and Nationalities of People Region, \\ Ethiopia
}

\begin{abstract}
Common bean production is severely infested by weeds in Wolaita Zone, Southern Ethiopia. Field experiment was conducted to assess the integrated effect of different weed management practices and herbicides on the growth and yield of common bean in 2014 at Wolaita Sodo. The experiment comprises of fifteen treatments which included two herbicides (MET and PEN ) applied as pre-emergence alone and in different combinations, HWH, weedy check all with and without mulching and weed free check laid out in randomized block design with three replications. Weed community recorded included $55.6 \%$ broadleaved, $33.3 \%$ grass and $11.1 \%$ sedge. The density of broadleaved, grass and sedge was significantly influenced by weed management practices both at 2 and 12 weeks after crop emergence (WAE). At 2 WAE, application of PEN $1.0 \mathrm{~kg}$ ha $-1+$ mulching resulted in significant decrease in total weed density over weedy check. At 12 WAE PEN $1.0 \mathrm{~kg}$ ha $-1+$ HWH 5 WAE significantly reduced broadleaved and total weed densities over the other treatments, while in case of grass weed, it was statistically in parity with MET $0.50 \mathrm{~kg}$ ha $-1+$ PEN $0.75 \mathrm{~kg}$ ha $-1+$ mulching, $\mathrm{HWH}$ at 2 and $5 \mathrm{WAE}$ and $\mathrm{HWH}$ at $2 \mathrm{WAE}$ supplemented with mulching. Weed dry weight varied significantly in response to weed management practices at 2 WAE. However, at 12 WAE this has no significant difference with PEN $1.0 \mathrm{~kg}$ ha -1 + HWH 5 WAE, MET $0.75 \mathrm{~kg}$ ha -1 + PEN $0.75 \mathrm{~kg}$ ha -1 + mulching and HWH at 2 and 5 WAE. Herbicide mixtures and mulching did not alter weeds infestation to a considerable level. Application of PEN $1.0 \mathrm{~kg} \mathrm{ha}{ }^{1}+$ HWH 5 WAE performed better than other herbicidal treatments in enhancing days to flowering and physiological maturity and increased yield attributing characters of common bean.
\end{abstract}

Keywords: Herbicides combination, mulch, PEN , preemergence, MET, weeds, yield

DOI: $10.7176 / \mathrm{JBAH} / 10-1-02$

Publication date: January $31^{\text {st }} 2020$

\section{INTRODUCTION}

\subsection{Background and Justification}

Haricot bean (Phaseolus vulgaris L.) is the second most important grain legume cultivated as cash crop in Ethiopia (CSA, 2011). In southern parts of the country, it is widely distributed and grown by farmers for various uses (Tenaw, 1990). The estimated production area and yield of common bean in Ethiopia in 2012/2013 cropping season were 366,876.94 hectare (ha) and 4,630,08.49 tons (t), respectively. In addition, the average national yield was reported to be $1262 \mathrm{~kg}$ ha -1 (Biru, 2014).

Even though common bean is largely grown in Ethiopia, the national average yield (0.5 to 0.8$)$ tone is far less than the attainable yield (2.5-3.0 $\mathrm{t} \mathrm{ha}^{-1}$ ) under good management conditions (Habtu et al., 1996). Low yield of common bean in Ethiopia is attributed to several production constraints which include lack of improved varieties for the agro-ecological zones, poor cultural practices, such as untimely and inappropriate field operations, weed infestation, low soil fertility, water stress, diseases and insect pests (Imru, 1985; Allen et al., 1989).

Weeds infestation is one of the main constraints in crop production in Ethiopia, especially during the rainy season. Weeds population reduced common bean seed yield and caused difficulties in the harvesting operation in cultivated areas (Majnoun Hosseini, 2008; Amini et al., 2013). Weeds increased the bean drying time in the field, resulting in yield losses due to shattering (Waters and Morishita, 2001). Red bean belongs to plants sensitive to weed competition. Its competition not only reduces the yield but also the bean quality, affecting seed size, plant height and pod length.

Farmers in the country are aware of weed problem in their fields but often they cannot cope-up with heavy weed infestation during the peak-period of agricultural activities because of labour shortage. Hence, most of their fields are weeded late or left un weeded. Such ineffective weed management is considered as the main factor for low average yield of common bean resulting in average annual yield loss of $36 \%$ to as high as $94 \%$ (Stroud, 1989). In addition to this, research result indicated that weed interference in common beans can result in yield losses up to 85\% (Dawit et al., 2011; Pynenburg et al., 2011; Mengesha et al., 2012). So, Increasing productivity of common bean is one of the ways to raise the living standards of the rural population and to ensure food security and poverty alleviation.

Hand weeding is the predominant weed control practice on smallholder farms (Vissoh et al., 2004). Although a lot of energy is expended in removing weeds by hand, crop yields are generally very low due to weed 
competition, as a result of untimely and ineffective weed control (Chikoye et al., 2004). On the other hand, research has shown that herbicides produce greater yield at less cost than the typical practice of hand weeding.

Chemical control is a better alternative to manual weeding because it is easier, cheaper, faster and gives better weed control (Chikoye et al., 2004). Most herbicides can control certain weed species at doses well below the recommended dose while other weed species require higher doses and yet others are not controlled even at the recommended dose. Therefore, appropriate herbicide mixtures can be utilized for broad spectrum weed control.

Mulching has a smothering effect on weeds by restricting light to the green portion or portion above the soil. Straw saw dust, plant residues and stubbles are used as mulching material. Moreover, mulching along with weed management practices may bring some promising effect on weed control and crop yield. Therefore, optimizing herbicide performance should be considered as one element in an integrated weed management strategy by integrating two or more direct weeding methods in combination to improve weed management in the immediate crop.

Several research publications (e.g. Singh et al., 1999; Singh et al., 2001; Dungarwal et al., 2003) have proved that integration of herbicides with hand weeding is the most effective and economical method of weed management. Thus, good weed control usually involves a combination of the available methods plus timeliness and good cultural practices (Abu-Hamdeh, 2003). Therefore, the objectives of the study were;

$>$ Assess the integrated effect of different weed management practices and herbicides on growth and yield of common bean

\section{MATERIALS AND METHODS}

\subsection{Description of Experimental Site}

The experiment was conducted at the Wolaita Sodo Agricultural, Technical and Vocational Education and Training (ATVET) College farm (6 ${ }^{\circ} 34^{\prime} \mathrm{N}$ latitude; 37²4'E longitude; altitude of 1954 m.a.s.l), Southern Nations, Nationalities and People's Region (SNNPR) in the main cropping season of 2014. It is situated at a distance of $383 \mathrm{~km}$ south of Addis Ababa and $157 \mathrm{~km}$ away from Awassa town. The site has a bimodal rainfall distribution pattern with average annual rainfall of $1572.3 \mathrm{~mm}$ and the average minimum and maximum air temperatures are $14.9{ }^{\circ} \mathrm{C}$ and $23.1{ }^{\circ} \mathrm{C}$, respectively (National Meteorology Agency, Wolaita Sodo branch 2014). The soil of the experimental field was sandy clay loam; $\mathrm{pH}$ is 5.5 and has low phosphorus and organic matter content (Wolaita Zone Soil Laboratory, 2014).

\subsection{Experimental Materials}

\subsubsection{Common bean}

Widely grown common bean variety 'Red Wolaita' was used for the experiment. It has an intermediate bush with prostrate stem with the ability to climb (growth habit III b). It was released by Institute of Agricultural Research (IAR) in 1974 (Amare, 1992) and has a yield potential of 1.9-2.1 ton ha-1 .

\subsubsection{Mulching}

The mulching material (grass) was cut and allowed to dry. Before applying, the mulch material was chopped into approximately 30 to $45 \mathrm{~cm}$ pieces.

\subsubsection{Herbicides}

MET and PEN were used for the experiment.

\subsection{Treatments and Experimental Design}

The experiment consists of fifteen weed management practices as indicated in Table 2. 
Table1 1. Treatment combinations

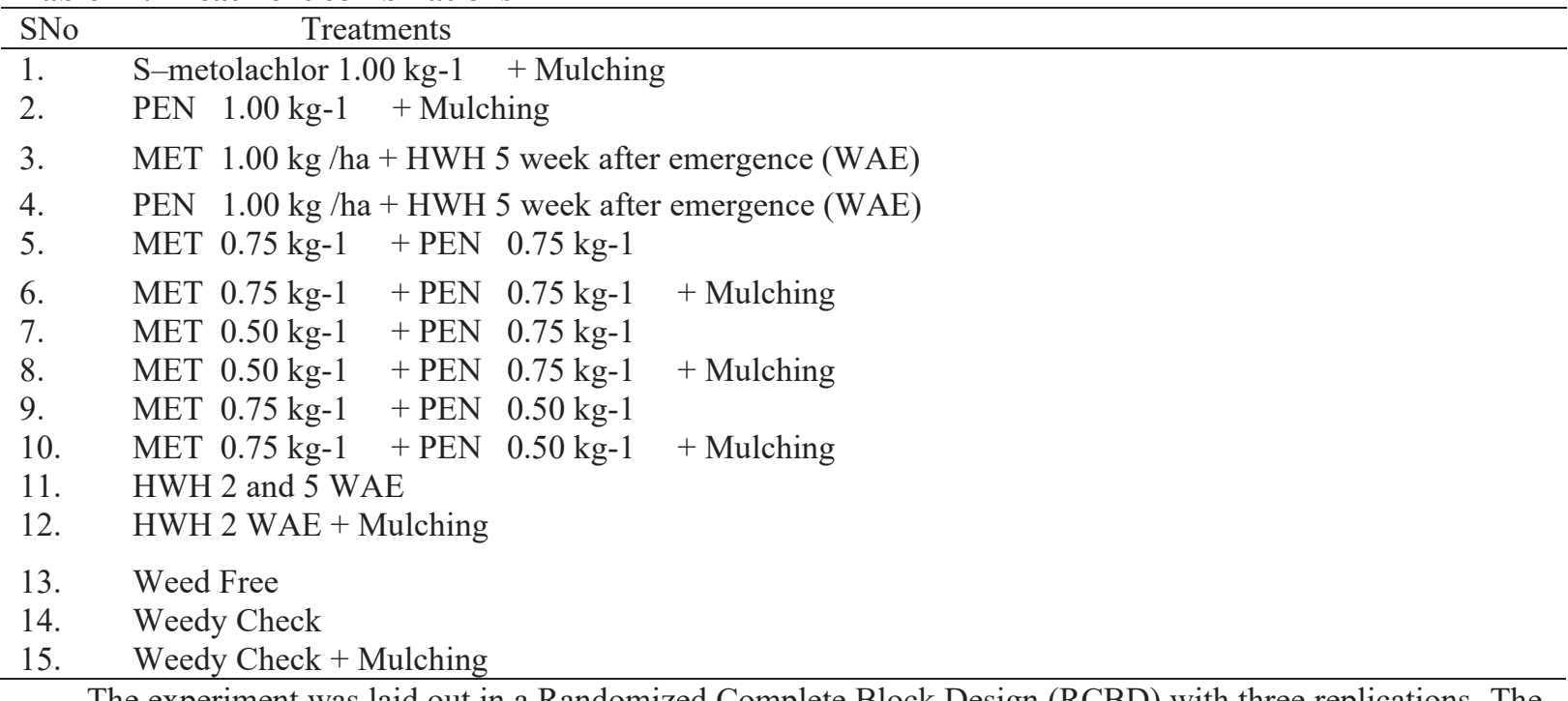

The experiment was laid out in a Randomized Complete Block Design (RCBD) with three replications. The size of the experimental plot was $3.0 \mathrm{~m} \times 2.4 \mathrm{~m}\left(7.2 \mathrm{~m}^{2}\right)$. The path width was $0.5 \mathrm{~m}$ between plots and $1.0 \mathrm{~m}$ between blocks. There were six rows spaced $40 \mathrm{~cm}$ and 30 plants each spaced $10 \mathrm{~cm}$ rows. The outer most two rows and two plants from each end of the rows were considered as border. Thus, the net plot size was $2.6 \mathrm{~m} \times 1.6$ $\mathrm{m}\left(4.16 \mathrm{~m}^{2}\right)$.

\subsection{Crop Management}

The experimental field was ploughed twice to get fine seed bed. Each plot was levelled manually after the field layout was made. Planting was done at a specified inter and intra row spacing on June $1^{\text {st }} 2014$. Two common bean seeds were placed per hill and later a thinned to one plant after emergence. The recommended amount of nutrient (18 kg N+ $\left.46 \mathrm{~kg} \mathrm{P}_{2} \mathrm{O}_{5} / \mathrm{ha}\right)$ was applied through $100 \mathrm{~kg}$ DAP $\left(18 \% \mathrm{~N} ; 46 \% \mathrm{P}_{2} \mathrm{O}_{5}\right)$ in furrows at the time of sowing.

Herbicidal treatments were applied as pre emergence onto the soil one day after planting with Knapsack sprayer using Flat fan nozzle in specified plots. The spray volume water as a carrier was $5001 / \mathrm{ha}$

In treatments that included combined use of herbicide and mulching, the mulching was done immediately after spray. In hand weeding plots, it was done after hand weeding while in the other plots it was done after sowing. Mulch material was spread uniformly on soil surface with a thickness of approximately 10-15 cm layer and hand pulling was made in weed free plot periodically. All the other practices were followed as per the recommendation to raise the crop. Harvesting of the crop was done on August 29, 2014.

\subsection{Data Collected}

\subsubsection{Weed parameters}

3.5.1.1 Weed community

The weeds in the weedy check plots were monitored once in month to ascertain the composition of weed community in the experiment.

\subsubsection{Weed density and dry weight}

The weed density was recorded with the use of quadrate $(0.25 \mathrm{~m} \times 0.25 \mathrm{~m})$ thrown randomly at two places in each plot. Weeds with their root system falling within each quadrate were counted and categorized as broadleaved, grass and sedges and converted in to density $\mathrm{m}^{-2}$ before hand weeding and 15 days before crop harvest which was designated as at harvest. After recording the data on density, plot wise weeds within each quadrate were cut near the soil surface and placed into paper bags. Weeds were dried in sun for 3 days and then were placed and dried in an oven at $65^{\circ} \mathrm{C}$ till constant weight. Their weight was expressed in dry weight $\mathrm{g} \mathrm{m}^{-2}$.

\subsubsection{Crop parameters}

\subsubsection{Crop phenology and growth}

Days to $50 \%$ flower initiation, Days to physiological maturity and Plant height were used.

\subsubsection{Yield and yield attributes}

Crop plant stand, Number of pods per plant, Number of seeds per pod, 100 grain weight (g), Aboveground dry matter, Harvest index and Grain yield $(\mathrm{kg})$ were used to conduct this experiment.

Adjusted yield (kg) = Recorded seed weight x 100-M

$$
\text { 100-D }
$$

Where $\quad \mathrm{M}=$ Measured moisture content in grain; $\mathrm{D}=$ Designated moisture content 


\subsection{Data Analysis}

All data were subjected to analysis of variance (ANOVA) for randomized complete block design as per Gomez and Gomez (1984) and analyzed using Gen statistical analysis software version 12.1(GenStat, 2012). Difference between means was compared using the least significant difference (LSD) procedure at 5 percent level of significance.

\section{RESULTS AND DISCUSSION \\ 4.1 Weed Component \\ 4.1.1 Weed density}

4.1.1.1 Weed density at 2 weeks after emergence (WAE)

Analysis of variance revealed highly significant $(\mathrm{P}<0.01)$ difference in broadleaved, grass, sedge and total weed density at 2 WAE due to weed control treatments (Appendix 1).

At $2 \mathrm{WAE}$, the density of broadleaved weeds was lower than the other treatments due to the application of PEN at $1.0 \mathrm{~kg}$ ha -1 supplemented with mulching. It was also observed that MET $0.75 \mathrm{~kg}$ ha $-1+$ PEN $0.75 \mathrm{~kg}$ $\mathrm{ha}^{-1}$ and MET $0.75 \mathrm{~kg} \mathrm{ha}^{-1}+$ PEN $0.50 \mathrm{~kg}$ ha -1 when supplemented with mulching had significant reduction in broadleaved weed density over their respective application without mulching. Yadav et al. (2007) reported that mulch reduced the weed density and dry weight m-2 by $31 \%$ and $46.9 \%$, respectively over no mulch and also reported significantly more grain and straw yield than non-mulched crop.

The grass weeds population was lowest in MET $0.50 \mathrm{~kg}$ ha $-1+$ PEN $0.75 \mathrm{~kg}$ ha -1 . Radics and Bognar (2004) reported that mulching significantly limited weed germination, compared to non mulching control.

At $2 \mathrm{WAE}$, the total weed density though was lowest due to the application of PEN $1.0 \mathrm{~kg} \mathrm{ha}^{-1}+$ mulching. Hashim et al., (2002) reported that the maximum weed density was recorded in weedy check plots in their herbicidal trial in wheat.

Table 4. Effects weed management practices on weed density (m-2) at 2 WAE on common bean at Wolaita Sodo in 2014

\begin{tabular}{|c|c|c|c|c|c|c|c|}
\hline \multicolumn{4}{|l|}{ Treatments } & \multirow{2}{*}{$\frac{\text { Broadleaved }}{10.7^{\mathrm{abc}}(115.1)}$} & \multirow{2}{*}{$\frac{\text { Grass }}{6.6^{\mathrm{a}}(43.1)}$} & \multirow{2}{*}{$\begin{array}{l}\text { Sedge } \\
0.7^{\mathrm{c}}(0.0)\end{array}$} & \multirow{2}{*}{$\begin{array}{c}\text { Total } \\
12.6^{\mathrm{a}}(158.2)\end{array}$} \\
\hline MET $1.00 \mathrm{~kg}-1$ & + Mulcl & ing & & & & & \\
\hline PEN $1.00 \mathrm{~kg}-1$ & + Mulc & hing & & $7.7^{\mathrm{d}}(58.9)$ & $4.0^{\mathrm{cd}}(16.0)$ & $2.8^{\mathrm{b}}(8.0)$ & $9.1^{\mathrm{b}}(82.9)$ \\
\hline MET $1.00 \mathrm{~kg}-1$ & $+\mathrm{HWH}$ & 5 WAE & & $10.9^{\mathrm{abc}}(118.5)$ & $4.9^{\mathrm{abcd}}(23.6)$ & $0.7^{\mathrm{c}}(0.0)$ & $11.9^{\mathrm{ab}}(142.1)$ \\
\hline PEN $1.00 \mathrm{~kg}-1$ & $+\mathrm{HWH}$ & $5 \mathrm{WAE}$ & & $8.6^{\mathrm{cd}}(73.6)$ & $4.3^{\text {bcd }}(18.0)$ & $2.9^{\mathrm{b}}(8.0)$ & $10.0^{\mathrm{ab}}(99.6)$ \\
\hline MET 0.75 kg-1 & $+\mathrm{PEN}$ & $0.75 \mathrm{~kg}-1$ & & $11.5^{\mathrm{ab}}(132)$ & $6.3^{\mathrm{ab}}(39.3)$ & $0.7^{\mathrm{c}}(0.0)$ & $13.1^{\mathrm{ab}}(171.3)$ \\
\hline MET $0.75 \mathrm{~kg}-1$ & $+\mathrm{PEN}$ & $0.75 \mathrm{~kg}-1$ & + Mulching & $8.4^{\mathrm{cd}}(71.1)$ & $5.1^{\mathrm{abc}}(25.6)$ & $0.7^{\mathrm{c}}(0.0)$ & $9.8^{\mathrm{ab}}(96.7)$ \\
\hline MET $0.50 \mathrm{~kg}-1$ & $+\mathrm{PEN}$ & $0.75 \mathrm{~kg}-1$ & & $11.8^{\mathrm{ab}}(139.5)$ & $2.8^{\mathrm{d}}(7.4)$ & $0.7^{\mathrm{c}}(0.0)$ & $12.1^{\mathrm{ab}}(146.9)$ \\
\hline MET $0.50 \mathrm{~kg}-1$ & $+\mathrm{PEN}$ & $0.75 \mathrm{~kg}-1$ & + Mulching & $9.1^{\text {bcd }}(82.4)$ & $4.7^{\mathrm{abc}}(21.6)$ & $0.7^{\mathrm{c}}(0.0)$ & $10.2^{\mathrm{ab}}(104)$ \\
\hline MET $0.75 \mathrm{~kg}-1$ & $+\mathrm{PEN}$ & $0.50 \mathrm{~kg}-1$ & & $12.0^{\mathrm{a}}(145.3)$ & $6.0^{\mathrm{abc}}(35.1)$ & $0.7^{\mathrm{c}}(0.0)$ & $13.4^{\mathrm{a}}(180.4)$ \\
\hline MET $0.75 \mathrm{~kg}-1$ & $+\mathrm{PEN}$ & $0.50 \mathrm{~kg}-1$ & + Mulching & $8.5^{\mathrm{cd}}(72.6)$ & $4.2^{\text {bcd }}(17.2)$ & $0.7^{\mathrm{c}}(0.0)$ & $9.5^{\mathrm{ab}}(89.8)$ \\
\hline \multicolumn{4}{|c|}{$\mathrm{HWH}$ at 2 and $5 \mathrm{WAE}$} & $11.0^{\mathrm{abc}}(122.5)$ & $4.2^{\text {bcd }}(17.2)$ & $0.7^{\mathrm{c}}(0.0)$ & $11.8^{\mathrm{ab}}(139.7)$ \\
\hline \multicolumn{4}{|c|}{$\mathrm{HWH}$ at $2 \mathrm{WAE}+$ Mulching } & $10.6^{\mathrm{abc}}(113.1)$ & $4.1^{\mathrm{cd}}(16.4)$ & $0.7^{\mathrm{c}}(0.0)$ & $11.4^{\mathrm{ab}}(129.5)$ \\
\hline \multicolumn{4}{|l|}{ Weed Free } & $0.7^{\mathrm{e}}(0.0)$ & $0.71^{\mathrm{e}}(0.0)$ & $0.7^{\mathrm{c}}(0.0)$ & $0.7^{\mathrm{c}}(0.0)$ \\
\hline \multicolumn{4}{|l|}{ Weedy Check } & $11.6^{\mathrm{ab}}(135.3)$ & $5.2^{\mathrm{abc}}(26.6)$ & $4.1^{\mathrm{a}}(16.8)$ & $13.4^{\mathrm{a}}(178.7)$ \\
\hline \multicolumn{4}{|c|}{ Weedy Check + Mulching } & $12.0^{\mathrm{a}}(145.6)$ & $4.9^{\mathrm{abcd}}(23.6)$ & $3.4^{\mathrm{b}}(11.4)$ & $13.4^{\mathrm{a}}(180.6)$ \\
\hline \multicolumn{4}{|l|}{ LSD (0.05) } & 2.5 & 1.8 & 0.6 & 3.4 \\
\hline \multicolumn{4}{|l|}{$\mathrm{CV}(\%)$} & 15.4 & 24.2 & 24.8 & 18.8 \\
\hline
\end{tabular}

Means on the same column followed by the same letter are not significantly difference to each other; values out of the bracket are remove root transformed $\sqrt{x+0.5}$ ), while inside bracket are original values.

\subsubsection{Weed density at 12 weeks after emergence (WAE)}

Analysis of variance revealed highly significant $(\mathrm{P}<0.01)$ difference in broadleaved, grass, sedge and total weed density at 2 WAE due to weed control treatments (Appendix 2).

The density of broadleaved weeds due to application of PEN $1.0 \mathrm{~kg}$ ha $-1+$ hand weeding 5 WAE was statistically in parity with weed free. Both these treatments had significantly lower density than the other treatments at 12 WAE. These treatments were followed by HWH at 2 and 5 WAE which had statistically similar broadleaved density to that obtained with the application of PEN $1.0 \mathrm{~kg}$ ha $-1+$ mulching, MET $0.50 \mathrm{~kg}$ ha $-1+$ PEN $0.75 \mathrm{~kg}$ ha -1 + mulching and MET $0.75 \mathrm{~kg}$ ha $-1+$ PEN $0.50 \mathrm{~kg}$ ha $-1+$ mulching. It was also observed that supplementing respective herbicide mixtures with mulching though resulted in reduced broadleaved weed density, it was significant in case of MET $0.75 \mathrm{~kg}$ ha $-1+$ PEN $0.50 \mathrm{~kg}$ ha -1 . This indicated that mulching had no significant influence on reducing the broadleaved weed density except when MET $0.75 \mathrm{~kg}$ ha $-1+$ PEN 0.50 $\mathrm{kg}$ ha -1 was supplemented with mulching wherein mulching resulted in the reduction of broadleaved density by $54.7 \%$ over MET $0.75 \mathrm{~kg}$ ha $-1+$ PEN $0.50 \mathrm{~kg}$ ha -1 (Table 5). Weedy check with and without mulching had 
significantly higher broadleaved weed density than rest of the treatments. Sharma (1993) reported that an acceptable broadleaved weed control using PEN in peas. Khan et al. (2004) have also reported a maximum weed density in weedy check and weed control methods like application of herbicides and HWH significantly deceased weed density over weedy check.

The lowest grass weed density was also obtained with the application of PEN $1.0 \mathrm{~kg}$ ha $-1+$ HWH 5 WAE at 12 WAE. However, it had no significant difference with MET $0.75 \mathrm{~kg}$ ha $-1+$ PEN $0.75 \mathrm{~kg}$ ha $-1+$ mulching, MET $0.50 \mathrm{~kg}$ ha $-1+$ PEN $0.75 \mathrm{~kg}$ ha $-1+$ mulching, HWH 2 and $5 \mathrm{WAE}, \mathrm{HWH}$ at $2 \mathrm{WAE}+$ mulching. Like broadleaved weed density, the grass weed density was also significantly higher in weedy check than the other of the treatments.

The sedge density at 12 WAE was lowest with the application of with PEN $1.0 \mathrm{~kg}$ ha $-1+\mathrm{HWH} 5$ WAE and two hand weeding 2 and 5 WAE which was statistically in parity with PEN $1.0 \mathrm{~kg}$ ha $-1+$ mulching, MET $0.75 \mathrm{~kg}$ ha $-1+$ PEN $0.50 \mathrm{~kg}$ ha $-1+$ mulching, HWH at 2 and $5 \mathrm{WAE}, \mathrm{HWH}$ at $2 \mathrm{WAE}+$ mulching and weed free plots. As in case of broadleaved weed density, the sedge density was also significantly reduced with mulching when MET $0.75 \mathrm{~kg}$ ha $-1+$ PEN $0.50 \mathrm{~kg}$ ha -1 was supplemented with mulching. Weedy check had significantly higher sedge density than the other treatments.

Therefore, the reduced number of broadleaved, grass and sedges in these treatments was due to effective control of the weeds at all stages of crop growth period. The results are in conformity with findings of Dubey et al. (2005), Sanjoy Saha (2005 and 2009) and Singh et al. (2005) Who reported on significantly higher population of grasses, broad leaved weeds, sedges and their total dry weight was registered with unweeded check at harvest is due to no control of weeds.

The total weed density at 12 WAE obtained due to application of PEN $1.0 \mathrm{~kg}$ ha $-1+$ HWH 5 WAE resulted in lower weed density than the other weed management practices (Table 5). Supplementing herbicide mixtures MET $0.75 \mathrm{~kg}$ ha -1 + PEN $0.75 \mathrm{~kg}$ ha -1 and MET $0.75 \mathrm{~kg}$ ha -1 + PEN $0.50 \mathrm{~kg}$ ha -1 with mulching significantly reduced total weed density, while there was no significant difference among other mixtures with and without mulching.

The variability in weeds population in different treatments can be attributed to the fact that some herbicides are more effective for weed control than the others. Though PEN and MET are commonly used in various crops for control of small-seeded broadleaved weeds, some annual grasses, and yellow nuts sedge (Grichar et al., 1996) but in this experiment MET did not prove better than PEN in reducing total weed density.

Table 5. Effects weed management practices on weed density $\left(\mathrm{m}^{-2}\right)$ at 12 WAE on common bean at Wolaita Sodo in 2014

\begin{tabular}{|c|c|c|c|c|}
\hline Treatments & Broadleaved & Grass & Sedge & Total \\
\hline MET $1.00 \mathrm{~kg}-1+$ Mulching & $9.1^{\mathrm{cde}}(82.4)$ & $2.4^{\mathrm{de}}(5.4)$ & $3.0^{\mathrm{bcd}}(8.5)$ & $9.8^{\text {cde }}(96.3)$ \\
\hline PEN 1.00kg-1 + Mulching & $6.2^{\mathrm{efg}}(38.0)$ & $2.4^{\mathrm{de}}(5.4)$ & $1.2^{\mathrm{ef}}(1.1)$ & $6.7^{\mathrm{fg}}(44.5)$ \\
\hline MET $1.00 \mathrm{~kg}-1+$ HWH 5 WAE & $9.4^{\text {cde }}(87.9)$ & $4.3^{\mathrm{c}}(18.0)$ & $3.0^{\mathrm{bcd}}(8.5)$ & $10.7^{\mathrm{cde}}(114.4)$ \\
\hline PEN $1.00 \mathrm{~kg}-1+\mathrm{HWH} 5 \mathrm{WAE}$ & $1.4^{\mathrm{h}}(1.6)$ & $1.0^{\mathrm{fg}}(0.4)$ & $0.7^{\mathrm{f}}(0.0)$ & $1.6^{\mathrm{h}}(2.0)$ \\
\hline MET $0.75 \mathrm{~kg}-1+$ PEN $0.75 \mathrm{~kg}-1$ & $10.6^{\mathrm{cd}}(112.0)$ & $4.1^{\mathrm{c}}(16.4)$ & $2.9^{\text {cd }}(7.7)$ & $11.7^{\mathrm{cd}}(136.1)$ \\
\hline MET $0.75 \mathrm{~kg}-1+$ PEN $0.75 \mathrm{~kg}-1$ + Mulching & $7.8^{\operatorname{defg}}(60.1)$ & $2.0^{\mathrm{def}}(3.4)$ & $2.1^{\mathrm{cde}}(4.0)$ & $8.2^{\mathrm{ef}}(67.5)$ \\
\hline MET $0.50 \mathrm{~kg}-1+$ PEN $0.75 \mathrm{~kg}-1$ & $8.3^{\operatorname{def}}(68.3)$ & $2.6^{\mathrm{d}}(6.3)$ & $2.0^{\mathrm{de}}(3.5)$ & $8.9^{\text {def }}(78.1)$ \\
\hline MET $0.50 \mathrm{~kg}-1+$ PEN $0.75 \mathrm{~kg}-1+$ Mulching & $7.2^{\operatorname{defg}}(51.5)$ & $1.8^{\operatorname{defg}}(2.8)$ & $3.3^{\mathrm{bc}}(10.3)$ & $8.0^{\mathrm{ef}}(64.2)$ \\
\hline MET $0.75 \mathrm{~kg}-1+$ PEN $0.50 \mathrm{~kg}-1$ & $11.7^{\mathrm{bc}}(136.6)$ & $2.8^{\mathrm{d}}(7.6)$ & $2.7^{\mathrm{cd}}(7.2)$ & $12.3^{\mathrm{c}}(151.4)$ \\
\hline MET $0.75 \mathrm{~kg}-1+$ PEN $0.50 \mathrm{~kg}-1$ + Mulching & $5.3^{\mathrm{fg}}(27.6)$ & $2.8^{\mathrm{d}}(7.6)$ & $1.2^{\mathrm{ef}}(1.1)$ & $6.1^{\mathrm{fg}}(36.3)$ \\
\hline $\mathrm{HWH}$ at 2 and $5 \mathrm{WAE}$ & $4.7^{\mathrm{g}}(21.6)$ & $1.2^{\mathrm{efg}}(0.97)$ & $0.7^{\mathrm{f}}(0.0)$ & $4.8^{\mathrm{g}}(22.57)$ \\
\hline $\mathrm{HWH}$ at $2 \mathrm{WAE}+$ Mulching & $7.5^{\operatorname{defg}(55.7)}$ & $1.9^{\operatorname{defg}}(3.4)$ & $1.2^{\mathrm{ef}}(1.1)$ & $7.8^{\mathrm{ef}}(60.2)$ \\
\hline Weed Free & $0.7^{\mathrm{h}}(0.0)$ & $0.7^{\mathrm{g}}(0.0)$ & $0.7^{\mathrm{f}}(0.0)$ & $0.7^{\mathrm{h}}(0.0)$ \\
\hline Weedy Check & $16.7^{\mathrm{a}}(278.5)$ & $14.4^{\mathrm{a}}(207.6)$ & $5.3^{\mathrm{a}}(27.6)$ & $22.7^{\mathrm{a}}(513.7)$ \\
\hline Weedy Check + Mulching & $14.1^{\mathrm{a}}(198.1)$ & $12.5^{\mathrm{b}}(157.0)$ & $4.1^{\mathrm{b}}(16.3)$ & $19.3^{\mathrm{b}}(371.4)$ \\
\hline $\operatorname{LSD}(0.05)$ & 2.9 & 1.3 & 1.1 & 2.7 \\
\hline $\mathrm{CV}(\%)$ & 22.0 & 19.5 & 28.7 & 17.5 \\
\hline
\end{tabular}

Means on the same column followed by the same letter are not significantly difference to each other; values out of the bracket are remove root transformed $\sqrt{x+0.5}$ ), while inside bracket are original values.

\subsubsection{Dry weight of weeds}

Data pertaining to the effect of different weed management treatments presented in Table 5 showed that the lowest weed dry weight was found in PEN $1.0 \mathrm{~kg}$ ha $-1+\mathrm{HWH} 5$ WAE but it was statistically at par with other treatments except with MET $1.00 \mathrm{~kg}$ ha $-1+$ mulching, MET $1.0 \mathrm{~kg}$ ha $-1+$ HWH 5 WAE, MET $0.50 \mathrm{~kg}$ ha $-1+$ PEN $0.75 \mathrm{~kg}$ ha -1 with and without mulching, HWH at 2 and 5 WAE and hand weeding with mulching. The result also depicted that the weed dry biomass was not consistent with the weed density (Table 6). This could be due to the weeds were in their two to three leaf stage thus might not have accumulate advantage the dry weight 
to variable extent. However, Bhanumurthy and Subramanin (1989) opined that weed biomass is a better parameter to measure the competition than weed number as it precisely measures the quantity of growth related factors utilized by weeds. Application of herbicides not only reduced the density of weeds but also suppressed the weed growth bringing about lower dry weight. Singh and Bhandari (1986) reported that PEN (1 kg a.i. ha $\left.{ }^{-1}\right)$ or pretilachlor with safener $(0.5 \mathrm{~kg}$ a.i. ha-1) as pre-emergence applications followed by one hand-weeding were effective in controlling weeds, increasing grain yield of dry-seeded rice, and resulting in higher net returns than the weed-free treatment.

A minimum weed dry weight was registered in plots receiving two hand weeding 2 and $5 \mathrm{WAE}(1.0 \mathrm{~g} \mathrm{~m}-2)$ but it had no significant difference with weed dry weight obtained with the application of PEN $1.0 \mathrm{~kg}$ ha $-1+$ HWH 5 WAE $(1.7 \mathrm{~g} \mathrm{~m}-2)$ and MET $0.75 \mathrm{~kg}$ ha $-1+$ PEN $0.75 \mathrm{~kg}$ ha $-1+$ mulching at 12 WAE. Further, the first two treatments were as good as weed free in reducing the weed dry weight. At this stage, HWH at 2 WAE + mulching also proved at par with MET $0.75 \mathrm{~kg}$ ha $-1+$ PEN $0.75 \mathrm{~kg}$ ha -1 and PEN $1.0 \mathrm{~kg}$ ha $-1+$ mulching in reducing the weed dry weight.

Mohammad et al. (2007) achieved satisfactory weed control in wheat through herbicides in mixture than their alone application and hence produce less weed biomass but in contrast, in this experiment most of the herbicide mixtures did not prove better than many treatments. Similarly, metolachlor tank-mixed with either PEN or trifluralin had the widest range of weed control in snap beans (Stall and Hochmuth, 1989). Soltani et al. (2012) also reported that PEN at $1080 \mathrm{~g}$ ha-1 plus imazethapyr at 30, 45, 60, or $75 \mathrm{~g}$ a.i ha-1 applied pre plant incorporated has the potential for broad spectrum weed control in white bean. However, in agreement with Chhokar et al. (2007) mixture of herbicides effectively controlled weed flora than weedy check. Rao et al. (2009) investigated that pre-emergence application of atrazine $1.5 \mathrm{~kg}$ ha -1 followed by hand weeding at 30 DAS recorded lower weed dry weight at 60 DAS and harvest in maize. Kolhe (2001) also indicated that dry matter of weeds was significantly reduced due to application of PEN, MET, oxyfluorfen either alone or in combination with hand weeding at 35 DAP compared to weedy check in onion. Application of s- metolachlor $1.0 \mathrm{~kg}$ ha -1 supplemented either with mulching or hand weeding 5 WAE did not show appreciable reduction in weed dry weight compared to most of the treatments which could be due to its moderate persistence in the soil environment. Moreover, soils with significant soil water content may show more rapid breakdown (Kamrin, 1997) thus proving less effective. Sharma et al. (2004) found $1.5 \mathrm{~kg}$ ha -1 of MET to be effective for the control of weeds in common bean. But the selectivity and weed control greatly depend upon soil type, atmosphere temperature and rain fall. On the other hand, PEN is absorbed by plant roots and shoots and inhibits cell division and cell elongation (Kamrin, 1997). This inhibition of weeds plants might be responsible for the reduced density and dry weight of weeds.

The higher weed dry weight in weedy check might be due to higher weed density that provided an opportunity to the weeds to compete vigorously for nutrients, space, light, water and carbon dioxide resulting in higher biomass production. The results depicted that the application of PEN $1.0 \mathrm{~kg}$ ha -1 combined with one hand weeding provided prolonged weed control, and significant reduction in weed dry weight at harvest.

Table 6. Effect of different weed management practices on weed dry weight $\left(\mathrm{g} \mathrm{m}^{-2}\right)$ of common bean of Wolaita Sodo in 2014

\begin{tabular}{|c|c|c|c|c|c|}
\hline \multicolumn{4}{|c|}{ Treatment } & \multirow{2}{*}{$\begin{array}{l}2 \mathrm{WAE} \\
4.1^{\mathrm{abcd}}(16.6)\end{array}$} & \multirow{2}{*}{$\frac{12 \mathrm{WAE}}{8.3^{\mathrm{cde}}(68.4)}$} \\
\hline MET $1.00 \mathrm{~kg}-1$ & + Mulc & ling & & & \\
\hline PEN $1.00 \mathrm{~kg}-1$ & + Mulc & ing & & $3.0^{\mathrm{g}}(8.5)$ & $6.8^{\mathrm{ef}}(45.4)$ \\
\hline MET $1.00 \mathrm{~kg}-1$ & $+\mathrm{HWH}$ & 5 WAE & & $4.4^{\mathrm{abc}}(18.6)$ & $10.7^{\mathrm{c}}(114.0)$ \\
\hline PEN $1.00 \mathrm{~kg}-1$ & $+\mathrm{HWH}$ & $5 \mathrm{WAE}$ & & $3.4^{\mathrm{efg}}(11.1)$ & $1.7^{\mathrm{gh}}(2.4)$ \\
\hline MET $0.75 \mathrm{~kg}-1$ & + PEN & $0.75 \mathrm{~kg}-1$ & & $3.6^{\text {cdefg }}(12.5)$ & $6.3^{\text {ef }}(39.3)$ \\
\hline MET 0.75 kg-1 & $+\mathrm{PEN}$ & $0.75 \mathrm{~kg}-1$ & + Mulching & $3.2^{\mathrm{fg}}(9.8)$ & $3.1^{\text {gh }}(9.3)$ \\
\hline MET $0.50 \mathrm{~kg}-1$ & $+\mathrm{PEN}$ & $0.75 \mathrm{~kg}-1$ & & $3.9^{\text {bcdef }}(14.8)$ & $10.1^{\mathrm{cd}}(101.5)$ \\
\hline MET 0.50 kg-1 & $+\mathrm{PEN}$ & $0.75 \mathrm{~kg}-1$ & + Mulching & $3.7^{\text {cdef }}(13.2)$ & $8.0^{\text {cde }}(64.0)$ \\
\hline MET 0.75 kg-1 & $+\mathrm{PEN}$ & $0.50 \mathrm{~kg}-1$ & & $3.5^{\operatorname{defg}}(11.8)$ & $9.9^{\mathrm{cd}}(97.7)$ \\
\hline MET 0.75 kg-1 & $+\mathrm{PEN}$ & $0.50 \mathrm{~kg}-1$ & + Mulching & $3.2^{\mathrm{fg}}(9.8)$ & $7.4^{\mathrm{de}}(54.3)$ \\
\hline \multicolumn{4}{|c|}{$\mathrm{HWH}$ at 2 and $5 \mathrm{WAE}$} & $4.6^{\mathrm{ab}}(20.7)$ & $1.0^{\mathrm{h}}(1.0)$ \\
\hline \multicolumn{4}{|c|}{$\mathrm{HWH}$ at $2 \mathrm{WAE}+$ Mulching } & $4.0^{\text {bcde }}(15.5)$ & $4.3^{\mathrm{fg}}(18.0)$ \\
\hline \multicolumn{4}{|l|}{ Weed Free } & $0.7^{\mathrm{h}}(0.0)$ & $0.7^{\mathrm{h}}(0.0)$ \\
\hline \multicolumn{4}{|l|}{ Weedy Check } & $4.8^{\mathrm{a}}(22.6)$ & $20.1^{\mathrm{a}}(404.5)$ \\
\hline \multicolumn{4}{|c|}{ Weedy Check+ Mulching } & $3.9^{\text {bcdef }}(14.8)$ & $16.8^{\mathrm{b}}(281.5)$ \\
\hline \multicolumn{4}{|l|}{$\operatorname{LSD}(0.05)$} & 0.65 & 2.5 \\
\hline \multicolumn{4}{|l|}{ CV (\%) } & 10.9 & 19.2 \\
\hline
\end{tabular}

Means on the same column followed by the same letter are not significantly difference to each other; values out of the bracket are remove root transformed $\sqrt{x+0.5}$ ), while inside bracket are original values. 


\subsection{Crop Phenology and Growth}

\subsubsection{Days to $50 \%$ flower initiation}

Analysis of variance revealed highly significant $(\mathrm{P}<0.01)$ difference in days to $50 \%$ flower initiation in common bean due to weed control treatments (Appendix 4). It was noticed that days to $50 \%$ flowering was significantly earlier than the other treatments in plots treated with PEN at $1.0 \mathrm{~kg}$ ha -1 + hand weeding 5 WAE, except weed free. The days to attain $50 \%$ flowering were extended due to presence of weeds. However, it was statistically in parity with MET at $1.0 \mathrm{~kg}$ ha $-1+$ mulching. Similarly, the higher weed density and dry matter accumulation (Table 6) might have caused shading of crop plants that reduced sunlight penetration thus prolonging the vegetative growth resulting in delayed days to flowering. Further, it was observed that mulching did not significantly alter the days to 50\% flowering. Gupta (2011) showed that plants in unweeded plots took the highest time to reach 50\% flowering. On the other, hand Sunday and Udensi (2013) reported that weed competition delayed the number of days to $50 \%$ flowering in cowpea.

\subsubsection{Days to $90 \%$ physiological maturity}

Highly significant $(\mathrm{P}<0.01)$ differences were observed in different weeds management practices in days to physiological maturity (Appendix 4). It was observed that plants in plots treated with PEN at $1.0 \mathrm{~kg}$ ha $-1+$ hand weeding $5 \mathrm{WAE}, \mathrm{PEN}$ at $1.0 \mathrm{~kg}$ ha $-1+$ mulching, MET at $0.50 \mathrm{~kg}$ ha $-1+\mathrm{PEN}$ at $0.75 \mathrm{~kg}$ ha -1 and $\mathrm{HWH}$ at 2 and $5 \mathrm{WAE}$ and weed free matured significantly earlier than other treatments (Table 7). This was in agreement with the finding of Sunday (2013) who stated that treating plots with chemical and supplementing with hand weeding at intervals reduce number of days to maturity in cow pea ([Vigna unguiculata (L.) Walp.].

Table 7. Effects of weed management practices on days to flowering, days to physiological maturity and plant height $(\mathrm{cm})$ of common bean of Wolaita Sodo in 2014

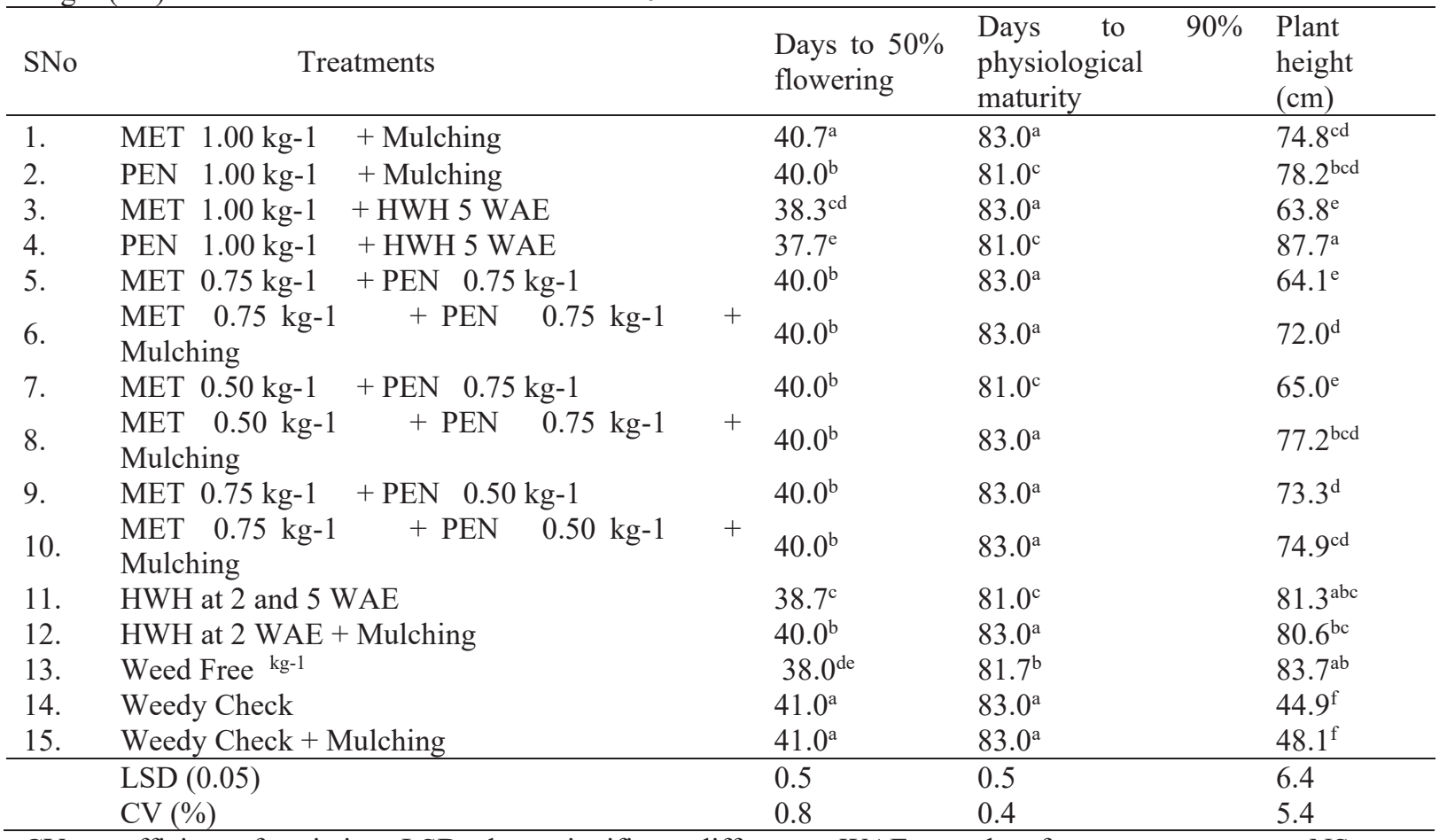

$\mathrm{CV}=$ coefficient of variation; $\mathrm{LSD}=$ least significant difference; WAE $=$ weeks after crop emergence; $\mathrm{NS}=$ not significant; Means in column of same parameter followed by the same letter(s) are not significantly different at $5 \%$ level of significance

\subsubsection{Plant height}

Analysis of variance showed highly significant $(\mathrm{P}<0.01)$ effects in plant height due to the treatments (Appendix 4). The plot treated with PEN $1.0 \mathrm{~kg}$ ha $-1+\mathrm{HWH} 5 \mathrm{WAE}$ resulted in highest plant height $(87.7 \mathrm{~cm})$ of common bean which did not differ significantly with $\mathrm{HWH}$ at 2 and 5 WAE and weed free (Table 7). Weedy check alone and in combination with mulching had significantly lower plant height than the other treatments. In general, mulching resulted in higher plant height than the unmulched treatments. However, significant difference existed when mulching was done over the respective application of MET $0.75 \mathrm{~kg}$ ha $-1+$ PEN $0.75 \mathrm{~kg}$ ha -1 and MET $0.50 \mathrm{~kg}$ ha $-1+$ PEN $0.75 \mathrm{~kg}$ ha -1 (Table 7) wherein mulching enhanced the plant height of common bean.

The plants in weedy check alone and with mulching attained significantly lower height than rest of the treatments. The lower plant height in weedy check might be due to competition of weeds for nutrients, moisture, light and space. The weed competition for growth resources resulted in reduction of plant height in dry bean as reported by Kavurmaci et al. (2010). In contrast Rohrig and Stutzel (2001) reported increase in plant height 
under weed competition is the result of increase in far red radiation compared to red radiation in consequence of shading.

Application of herbicides alone and supplemented with mulching or hand weeding as well as hand weeding resulted in significantly higher plant height $(63.8 \mathrm{~cm}$ to $87.7 \mathrm{~cm})$ than in weedy check (Table 7). The lowest plant height in weedy check with mulching $(44.9 \mathrm{~cm})$ was thus suppressed by 29.6 to $95.3 \%$ due to weeds. Current results are also in agreement with Jafari et al. (2013) who stated that pre emergence herbicides increased the plant height in common bean significantly as compared to weedy check.

The influence of organic mulches on crop yield is variable. Some authors reported that mulching improves plant growth, yield and yield quality Phaseolus vulgaris L. (Sharma and Sharma, 2003; Singh et al., 2007).

\subsection{Yield attributes and yield \\ 4.3.1 Crop stand count}

It was found that none of the weed management treatments resulted in significant variation in initial plant stand of common bean thus data not given. However, at harvest the crop stand count was significantly influenced by different weed management practices (Appendix 5). The highest stand count (243523 plants/ha) was recorded in weed free. However, it was statistically at par except with MET $0.50 \mathrm{~kg}$ ha $-1+$ PEN $0.75 \mathrm{~kg}$ ha -1 , MET 0.75 $\mathrm{kg}$ ha $-1+$ PEN $0.50 \mathrm{~kg}$ ha -1 , hand weeding 2 WAE supplemented with mulching and weedy check. Comparatively higher survival of the plants observed could be due to better competitive ability of crop plants for growth resources in the absence of weed competition.

The presence of higher weed density and weed dry weight might have lead to lower survival of crop plants. The high weed infestation might have resulted in severe competition for nutrients, light, space and moisture with the crop. Jakhar et al. (2012) pointed that two rotary weeding at 20 and 40 DAS reduced the growth of weeds resulted in higher weed control efficiency in soybean over all other weed control treatments.

\subsubsection{Number of pods per plant}

The highest number of pods per plant ( 9.9 pods/plant) was recorded under weed free which was statistically in parity with PEN at $1.0 \mathrm{~kg}$ ha $-1+\mathrm{HWH} 5 \mathrm{WAE}$. On the other hand, the latter treatment had no significant difference with MET $0.75 \mathrm{~kg}$ ha $-1+$ PEN $0.75 \mathrm{~kg}$ ha $-1+$ mulching, $\mathrm{HWH}$ at 2 and $5 \mathrm{WAE}$ and $\mathrm{HWH}$ at 2 $\mathrm{WAE}+$ mulching. Amongst various herbicide mixtures with and without mulching, MET at $0.75 \mathrm{~kg}$ ha $-1+\mathrm{PEN}$ at $0.75 \mathrm{~kg}$ ha $-1+$ mulching, recorded the highest number of pods/plant (8.4) which was statistically at par with MET at $0.50 \mathrm{~kg}$ ha $-1+$ PEN at $0.75 \mathrm{~kg}$ ha $-1+$ mulching and MET at $0.75 \mathrm{~kg}$ ha $-1+$ PEN at $0.50 \mathrm{~kg}$ ha -1 . This showed the superiority of MET at $0.75 \mathrm{~kg}$ ha $-1+$ PEN at $0.75 \mathrm{~kg}$ ha $-1+$ mulching over MET at $0.75 \mathrm{~kg}$ ha $-1+$ PEN at $0.75 \mathrm{~kg} \mathrm{ha}-1$, MET at $0.50 \mathrm{~kg}$ ha $-1+$ PEN at $0.75 \mathrm{~kg}$ ha -1 and MET at $0.75 \mathrm{~kg}$ ha $-1+$ PEN at $0.50 \mathrm{~kg}$ ha $-1+$ mulching. This indicated that mulching had positive effect when applied with higher rates of herbicide mixtures. This might be due to effective control of weeds with mixtures which was enhanced when supplemented with mulching. Weedy check decreased significantly number of pods/plant over other treatments and this decrease varied between 28.6 and $54.4 \%$ (Table 9).

Pod number per plant is the first yield component to be determined in the reproductive phase followed by seed per pod and seed weight (Woolley et al., 1993). Thus, among yield components, pod number per plant is likely to be the most sensitive yield component to weed interference. Ayaz et al. (2001) stated that the number of pods produced per plant or maintained to final harvest depends on a number of environmental and management practices. Mirshekari (1999) also showed that the presences of weeds are effective factor in reducing number of pods in cowpea plant. Dadari (2003) reported that competition between weeds and crop starts right from germination of the crop up to harvest affecting both growth and yield parameters adversely. Similar results were reported by Abu Hamdeh, (2003); Chmielowiec and Borowy (2004); Hossein (2005) and Tesfay and Amin (2013) in bean. 
Table 8. Effect of weed management practices on crop stand at harvest (ha ${ }^{-1}$ ), number of pods per plant, number of seeds per pod and hundred seed weight ( $\mathrm{g}$ ) of common bean at Wolaita Sodo in 2014

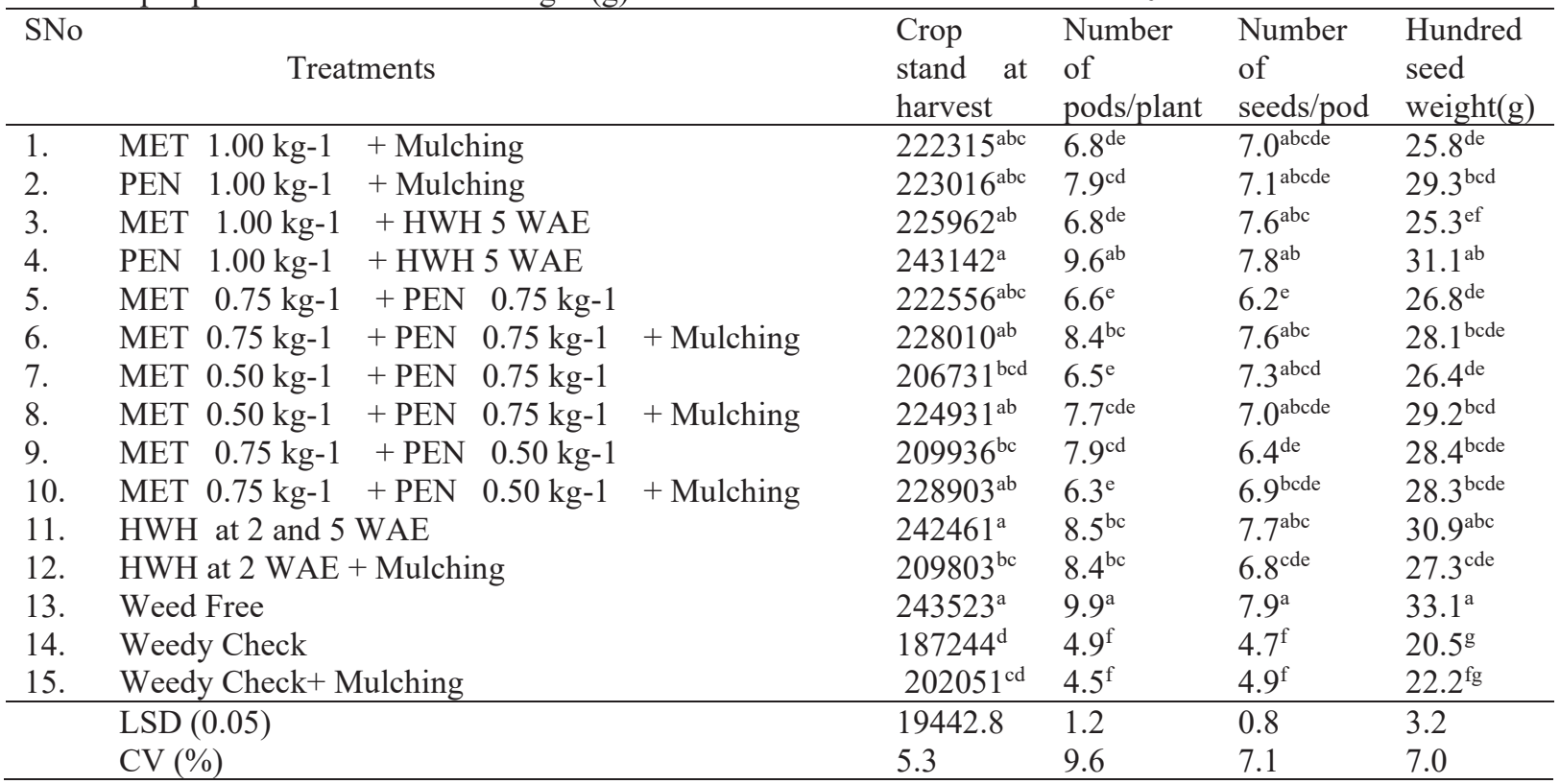

\subsubsection{Number of seeds per pod}

The number of seeds/pod was highly significantly $(\mathrm{P}<0.01)$ influenced by the treatments (Appendix 5). The highest number of seeds/pod $(7.9 \mathrm{seed} / \mathrm{pod})$ was obtained with complete weed free plots which was statistically in parity with PEN at $1.0 \mathrm{~kg}$ ha $-1+\mathrm{HWH} 5 \mathrm{WAE}, \mathrm{PEN}$ at $1.0 \mathrm{~kg}$ ha $-1+$ mulching, MET $1.0 \mathrm{~kg}$ ha $-1+$ HWH 5 WAE, MET $0.75 \mathrm{~kg}$ ha $-1+$ PEN $0.75 \mathrm{~kg}$ ha -1 mulching MET $0.50 \mathrm{~kg}$ ha $-1+$ PEN $0.75 \mathrm{~kg}$ ha -1 and HWH 2 and 5 WAE. In general, mulching helped in improving the number of seeds/pod, but it was not significant except in treatments MET at $0.75 \mathrm{~kg}$ ha $-1+\mathrm{PEN}$ at $0.75 \mathrm{~kg}$ ha -1 in which mulching increased number of seeds per pod by $22.6 \%$ (Table 9). It was also observed that one HWH at 2 WAE when supplemented with mulching proved statistically inferior to two HWH at 2 and 5 WAE.

The untreated control gave the least number of seeds/ pod and the differences with other treatments were significant (Table 9). The lowest number of seeds per pod in weedy check treatment may be due to high weed infestation during the growing period of the crop. This result agreed with the findings of Tenaw et al. (1997) and Sharma et al. (2004) who reported that number of seeds pod-1 was significantly reduced with the increased weed infestation and significantly increased with the weed free period in common bean. These results are in agreement with the findings of Jafari et al. (2013) in bean, who stated that pre emergent herbicides increased the plant height, pods per plant and seed number per pod significantly as compared to weedy check.

\subsubsection{Hundred grain weight}

Analysis of variance indicated highly significant $(\mathrm{P}<0.01)$ difference in hundred seed weight among the treatments (Appendix 5). Weight of hundred seeds was maximum with complete weed free which was statistically in parity with the application of PEN at $1.0 \mathrm{~kg}$ ha $-1+\mathrm{HWH}$ at $5 \mathrm{WAE}$ and two HWH 2 and 5 WAE treatments. This might be in general, due to more and vigorous leaves under reduced weed competition which improved the supply of assimilate to be stored in the grain, hence, the hundred seed weight increased. Furthermore, the higher hundred seed weight recorded from these treatments might be due to availability of more space for better light interception, resulting in better utilization of other growth resources for grain development. No significant difference was found between mulching and non mulching when plots were treated with MET at $0.75 \mathrm{~kg}$ ha $-1+\mathrm{PEN}$ at $0.75 \mathrm{~kg}$ ha -1 , MET at $0.50 \mathrm{~kg} \mathrm{ha-1}+\mathrm{PEN}$ at $0.75 \mathrm{~kg}$ ha -1 , and MET at $0.75 \mathrm{~kg}$ ha -1 + PEN at $0.50 \mathrm{~kg}$ ha -1 and weedy check. However, 100 seed weight was significantly lower in weedy check with and without mulching than the other treatments (Table 9). Reduced weight of 100 seeds observed at weedy check treatments which might have resulted due to high weed infestation. This result was in agreement with those of Spader and Vidal (2000) who noted decrease in grain weight of maize with an increase in weed density. Yield losses caused by weed competition are mainly due to delayed weeding or insufficient weed control (Akibode, 2011).

\subsubsection{Grain yield}

The treatments showed significant $(\mathrm{P}<0.01)$ difference in grain yield (Appendix 6). The highest yield $(1982 \mathrm{~kg}$ ha -1 ) was obtained with the application of PEN at $1.0 \mathrm{~kg}$ ha -1 + hand weeding at 5 WAE which was statistically in parity with two hand weeding at 2 and 5 WAE and complete weed free. Further, HWH at 2 and 5 WAE was statistically in parity with PEN at $1.0 \mathrm{~kg}$ ha $-1+$ mulching. Suppression of weed competition was 
further enhanced by integrating hand weeding kept the crop weed free during critical periods of 35 DAE which offered prolonged and efficient weed control thus reducing weed crop competition (Mondal et al., 2005; Warade et al., 2006.)

\subsubsection{Aboveground dry biomass yield}

The comparison of the mean values of the biomass yield showed that the highest biomass yield (4773 $\mathrm{kg} \mathrm{ha}-1)$ of common bean was obtained with application of PEN at $1.0 \mathrm{~kg}$ ha -1 + HWH 5 WAE which was statistically at par with the aboveground dry biomass yield obtained with the application of MET at $1.0 \mathrm{~kg} \mathrm{ha}-1+\mathrm{HWH}$ at $5 \mathrm{WAE}, \mathrm{HWH}$ at 2 and $5 \mathrm{WAE}$ and weed free. On the other hand, mulching had no beneficial effect on aboveground dry biomass over their respective herbicide mixtures.

It was also revealed that application of MET at $1.0 \mathrm{~kg}$ ha -1 when superimposed with hand weeding at 5 WAE did not show significant improvement in aboveground dry biomass over MET at $1.0 \mathrm{~kg}$ ha $-1+$ mulching. The results was in conformity with the findings of Sadegh (2013) who reported that among the weeds control methods, the highest biomass yield was obtained at application of Bentazon + once handing weeds treatment and the lowest biomass yield was at control treatment in red bean (Phaseolus vulgaris L.).

\subsubsection{Harvest index}

The comparison of the mean values of the harvest index showed that PEN $1.0 \mathrm{~kg}$ ha $-1+$ HWH 5 WAE treatment has the highest $(39.5 \%$ ) harvest index (Table 10) but in parity with PEN $1.0 \mathrm{~kg}$ ha-1, MET $0.50 \mathrm{~kg}$ ha $-1+$ PEN $0.75 \mathrm{~kg}$ ha -1 with mulching, HWH at 2 and $5 \mathrm{WAE}$ and weed free. Among the treatments, non significance difference was obtained with mulching except PEN $1.0 \mathrm{~kg}$ ha $-1+\mathrm{HWH} 5 \mathrm{WAE}$ plot. Among the weeds control treatments, the lowest harvest index (20.5\%), was belonged at weedy check and weedy check plus mulching treatment $(22.2 \%)$. This lower harvest index might be the result of weed competition with the crop for the growth and development of the crop. Besides to this, reduction in harvest index could be the result of the vulnerability of dry bean reproductive phase to weed interference. Dawit et al. (2011) reported as herbicide followed by twice hand weeding gave high harvest index.

Table 9.Yield attributes and yield of common bean as influenced by weed control methods at Wolaita Sodo in 2014

\begin{tabular}{|c|c|c|c|c|c|c|}
\hline SNo & \multicolumn{3}{|c|}{ Treatments } & $\begin{array}{l}\text { Aboveground dry } \\
\text { biomass (kg ha - } \\
1 \text { ) }\end{array}$ & $\begin{array}{l}\text { Grain } \\
\text { yield } \\
(\mathrm{kg} \text { ha - } \\
1 \text { ) }\end{array}$ & $\begin{array}{l}\text { Harvest } \\
\text { index } \\
(\%)\end{array}$ \\
\hline 1. & MET $1.00 \mathrm{~kg}-1$ & \multicolumn{2}{|l|}{ + Mulching } & $4430^{\mathrm{bc}}$ & $1446^{\mathrm{cd}}$ & $32.6^{\text {abcde }}$ \\
\hline 2. & PEN $1.00 \mathrm{~kg}-1$ & \multicolumn{2}{|l|}{+ Mulching } & $4444^{\mathrm{bc}}$ & $1672^{b c}$ & $37.6^{\mathrm{abc}}$ \\
\hline 3. & MET $1.00 \mathrm{~kg}-1$ & \multicolumn{2}{|l|}{+ HWH 5 WAE } & $4798^{\mathrm{ab}}$ & $1455^{\mathrm{cd}}$ & $30.4^{\text {cde }}$ \\
\hline 4. & PEN $1.00 \mathrm{~kg}-1$ & \multicolumn{2}{|l|}{ + HWH 5 WAE } & $5013^{\mathrm{a}}$ & $1982^{\mathrm{a}}$ & $39.5^{\mathrm{a}}$ \\
\hline 5. & MET $\quad 0.75 \mathrm{~kg}-1$ & \multicolumn{2}{|l|}{$+\mathrm{PEN} \quad 0.75 \mathrm{~kg}-1$} & $4236^{\mathrm{c}}$ & $1309^{d}$ & $30.9^{\text {bcde }}$ \\
\hline 6. & MET $0.75 \mathrm{~kg}-1$ & $+\mathrm{PEN} \quad 0.75 \mathrm{~kg}-1$ & \multirow[t]{2}{*}{ + Mulching } & $4321^{\mathrm{c}}$ & $1584^{\mathrm{c}}$ & $36.7^{\mathrm{abc}}$ \\
\hline 7. & MET $0.50 \mathrm{~kg}-1$ & $+\mathrm{PEN} \quad 0.75 \mathrm{~kg}-1$ & & $4195^{c}$ & $1466^{\mathrm{cd}}$ & $35.0^{\mathrm{abcd}}$ \\
\hline 8. & MET $0.50 \mathrm{~kg}-1$ & $+\mathrm{PEN} \quad 0.75 \mathrm{~kg}-1$ & \multirow[t]{2}{*}{ + Mulching } & $4225^{\mathrm{c}}$ & $1583^{c}$ & $37.5^{\mathrm{abc}}$ \\
\hline 9. & MET $\quad 0.75 \mathrm{~kg}-1$ & + PEN $\quad 0.50 \mathrm{~kg}-1$ & & $4279^{c}$ & $1530^{\mathrm{cd}}$ & $35.8^{\mathrm{abcd}}$ \\
\hline 10. & MET $0.75 \mathrm{~kg}-1$ & $+\mathrm{PEN} \quad 0.50 \mathrm{~kg}-1$ & + Mulching & $4397^{\mathrm{bc}}$ & $1606^{\mathrm{c}}$ & $36.5^{\mathrm{abc}}$ \\
\hline 11. & \multicolumn{3}{|c|}{ HWH at 2 and 5 WAE } & $5008^{\mathrm{a}}$ & $1885^{\mathrm{ab}}$ & $37.6^{\mathrm{abc}}$ \\
\hline 12. & \multicolumn{3}{|c|}{$\mathrm{HWH}$ at $2 \mathrm{WAE}+$ Mulching } & $4452^{\mathrm{bc}}$ & $1566^{\mathrm{c}}$ & $35.2^{\mathrm{abcd}}$ \\
\hline 13. & \multicolumn{3}{|c|}{ Weed Free } & $5016^{\mathrm{a}}$ & $1920^{\mathrm{a}}$ & $38.3^{\mathrm{ab}}$ \\
\hline 14. & \multicolumn{3}{|l|}{ Weedy Check } & $3442^{\mathrm{d}}$ & $937^{\mathrm{e}}$ & $27.2^{\mathrm{e}}$ \\
\hline 15. & \multicolumn{3}{|c|}{ Weedy Check + Mulching } & $3453^{\mathrm{d}}$ & $1012^{\mathrm{e}}$ & $29.3^{\mathrm{de}}$ \\
\hline & \multicolumn{3}{|l|}{$\operatorname{LSD}(0.05)$} & 423.1 & 223.3 & 6.3 \\
\hline & \multicolumn{3}{|l|}{$\mathrm{CV}(\%)$} & 5.8 & 8.7 & 10.8 \\
\hline
\end{tabular}

\section{SUMMARY AND CONCLUSION}

The common bean field was infested with nine weed species which belonged to five families out of which $55.6 \%$, $33.3 \%$ and $11.1 \%$ were broadleaved, grass and sedge, respectively.

At 2 and $12 \mathrm{WAE}$, the density of broadleaved weeds was lower than the other treatments in plots treated with PEN at $1.0 \mathrm{~kg}$ ha -1 supplemented with mulching while grass weed density was lowest in MET $0.50 \mathrm{~kg}$ ha $1+$ PEN $0.75 \mathrm{~kg}$ ha- 1 . The total weed density though was lowest due to the application of PEN $1.0 \mathrm{~kg}$ ha $-1+$ mulching it had no significant difference except with MET $1.0 \mathrm{~kg}$ ha $-1+$ mulching, combination of MET + PEN $(0.75+0.75 \mathrm{~kg}$ ha -1$),(0.75+0.50 \mathrm{~kg}$ ha -1$),\left(0.50+0.75 \mathrm{~kg} \mathrm{ha}^{-1}\right)$ and weedy check with and without mulching.

The sedge and total weed density was also lowest with the application of PEN $1.0 \mathrm{~kg}$ ha $-1+$ HWH 5 WAE. 
Supplementing herbicide mixtures MET + PEN $(0.75+0.75 \mathrm{~kg}$ ha -1$)$ and $(0.75+0.50 \mathrm{~kg}$ ha -1$)$ with mulching significantly reduced total weed density, while there was no significant difference among other mixtures with and without mulching. Weedy check had significantly higher broadleaved, grass, sedge and total weed density than the other treatments at 12 WAE. At 2 WAE, the lowest weed dry weight was found in PEN $1.0 \mathrm{~kg} \mathrm{ha}-1+$ HWH 5 WAE.

The number of days to $50 \%$ flowering and physiological maturity was earlier than the other treatments in plots treated with PEN at $1.0 \mathrm{~kg} \mathrm{ha}^{-1}+$ hand weeding 5 WAE.

Weed infestation throughout the growing period suppressed the plant height by about 29.6 to $95.3 \%$ compared to other treatments. Similarly survival of crop plants at harvest was also affected to variable extent due to weed management practices.

The highest number of pods per plant was recorded under complete weed free and it was statistically in parity with PEN at $1.0 \mathrm{~kg}$ ha $-1+\mathrm{HWH} 5 \mathrm{WAE}$. Weedy check resulted in significant decrease in number of pods per plant which varied between 28.6 and $54.4 \%$ over other treatments.

The highest number of seeds/pod was also obtained with complete weed free plots but in addition to PEN at $1.0 \mathrm{~kg}$ ha $-1+$ HWH 5 WAE. Mulching helped in improving the number of seeds/pod, but it was not significant except in treatment MET at $0.75 \mathrm{~kg}$ ha $-1+$ PEN at $0.75 \mathrm{~kg}$ ha -1 in which mulching increased number of seeds per pod by $22.6 \%$.

Weight of hundred seeds was maximum with complete weed free which treatments were statistically in parity with the application of PEN at $1.0 \mathrm{~kg}$ ha $-1+\mathrm{HWH}$ at $5 \mathrm{WAE}$ and two HWH 2 and 5 WAE.

The highest biomass yield (4773 $\left.\mathrm{kg} \mathrm{ha}^{-1}\right)$, Highest harvest index (39.5\%) and yield (1982 $\mathrm{kg} \mathrm{ha-1)} \mathrm{of}$ common bean was obtained with application of PEN at $1.0 \mathrm{~kg}$ ha-1+ HWH 5 WAE.

Generally, from results of the experiment, it could be concluded that PEN $1.0 \mathrm{~kg}$ ha -1 combined with one $\mathrm{HWH}$ at 5 WAE was the most appropriate method for effective weed management and profitable production of common bean in Woliata Sodo.

\section{REFERENCES}

Abu-Hamdeh, N.H. 2003. Effect of weed control and tillage system on net returns from bean and barley production in Jordan. Canadian Bio Systems Engineering, 45: 223-228.

Ahmed, Z.I., Ansar, M., Iqbal, M., Minhas, N.M. 2007. Effect of planting geometry and mulching on moisture conservation, weed control and wheat growth under rain fed conditions. Pakistan Journal of Botany, 39(4): 1189-1195.

Akibode, C.S. 2011. Trends in Production, Trade and Consumption of Food Legume Crops in Sub Saharan Africa. M.Sc. Thesis. Michigan University USA: 4-9.

Amare Abebe.1987. "Haricot bean (Phaseolus vulgaris L.) Varieties performance and recommended method of production", In: proceedings of the $19^{\text {th }}$ National Crop Improvement Conference, 22-26 April 1987, IAR, Addis Ababa, Ethiopia.

Arentoft, B.W., Ali, A., Streibig, J.C. and Andresen, C. 2013. A new method to evaluate the weed-suppressing effect of mulches: a comparison between spruce bark and cocoa husk mulches. Weed Research, 53: 169175.

Ayaz, S., McNeil, D.L., McKenzie, B.A. and Hill, G.D. 2001. Density and sowing depth effects on yield components of grain legumes. Proceeding of Agronomy Society, New Zealand, 29: 9-15.

Bhanumurthy, V.B. and Subramanin, S. 1989. Adoptattion of new parameters, gram day competitions for weed control study. Indian Journal of Agricultural Sciences, 59(4):800-801.

Biru Alemu. 2014. Adaptation Study of Improved Haricot Beans (Phaseolus vulgaris L.) Varieties at Western Oromia, Haro Sabu, Ethiopia. Haramaya University, Department of plant Science, Post graduate student, Dire Dawa, Ethiopia.

Chhokar, R.S., Sharma, R.K., Jat, G.R., Pundir, A.K. and Gathala, M.K. 2007. Effect of tillage and herbicides on weeds and productivity of wheat under rice-wheat-growing system. Crop Prot., 26(11):1689-1696.

Chikoye, D., Schultz, S. and Ekeleme, F. 2004. Evaluation of Integrated Weed Management Practices for Maize in the Northern Guinea Savannah of Nigeria. Crop Protection, 23:895-900.

Chmielowiec, 1., Borowy, A. 2004. Ocena działania bentazonu i metolachloru w uprawie fasoli zwykłej (Phaseolus vulgaris L.) 'BONA'./Evaluation of the effect of bentazon and s-metolachlor in common bean (Phaseolus vulgaris L.) 'Bona' crops. Act. Sci. Pol., Hortorum Cultus, 3 (1):75-87 (in Polish).

CSA (Central statistical Agency). 2011. Statistical report on area of production of crops. Central statistical agency, Addis Ababa.

CSA (Central Statistics Agency). 2012/13. Report on area and crop production forecast for major crops. Meher season, Statistical Bulletin 2012; 128 pp.

CSA (Central Statistical Agency). 2013/14. Federal Democratic Republic of Ethiopia, Agricultural sample survey. Report on Area and production of Major crops. Private peasant holdings, in 2013/14 Meher season. 
Statistical bulletin 532. Addis Ababa, Ethiopia. 12P.

Dadari, S.A. 2003. Evaluation of herbicides in cowpea/cotton mixture in Northern Guinea Savannah. Journal of Sustainable Agriculture and Environment, 5:153 - 159.

Dawit Dalga, Sharma, J.J. and Lisanework Nigatu. 2011. Effect of pendimethalin and s- metolachlor application rates on weed dynamics and yield of common bean (Phaseolus vulgaris L.) at Areka, Ethiopia. Ethiopian Journal of Weed Management, 11:37-53.

Dubey, K.V., Juwarkar, A. and Singh, S.K. 2005. Adsorption-desorption process using wood-based activated carbon for recovery of bio surfactant from fermented distillery waste water. Biotechnol. Prog., 21:860-867.

GenStat. 2009. GenStat Release 12.1. PC/windows XP/ $12^{\text {th }}$ edition 06 January. Copy right 2009 . VSN. International. Ltd.

Grichar, W., Colburn, A. and Baughman, P. 1996. Yellow nut sedge (Cyperus esculents) control in peanut (Arachis hypogaea) as influenced by method of s-metolachlor application. Weed Technol., 10:278-281.

Gupta, O.P. 2011. Modern Weed Management. $4^{\text {th }}$ edition. Agrobios Jodhpur, India. 615p.

Habtu Assefa. 1994. Epidemiology of bean rust in Ethiopia. Ph.D Thesis, Netherlands: Wageningen Agricultural University. 172p.

Hashim, S., Marwat, K.B. and Hassan, G. 2002. Response of wheat verities to substituted urea herbicides. Pak. J. Weed Sci., 89(1-2):49-55.

Hossein, G. 2005. Weed Interference Affects Dry Bean Yield and Growth. Bu-Ali Sina University, Faculty of Agriculture, Department of Agronomy and Plant Breeding, Janbazan Street, Amedan, Iran; Ghamari130@gmail.com (corresponding author). Available online at www.notulaebiologicae.ro.

Jafari, R., Rezai, S., Shakarami, J. 2013. Evaluating effects of some herbicides on weeds in field bean (Phaseolus vulgaris). International Research Journal of Applied and Basic Sciences, 6 (8):1150-1152.

Jakhar, R.R., Sharma, R., Singh, S.B. and Shukla, L. 2012. Integrated weed management in soybean. In: Third International Agronomy Congress on "Agriculture diversification, climate change management and livelihoods, held at Indian Agricultural Research Institute, New Delhi, pp: 227-228.

Kamrin Michael, A. 1997. Pesticides profiles: Toxicity, Environmental Impact and Fate .Boca Raton, New York.

Kavurmaci, Z., Karadavut, U., Kökten, K. and Bakoğlu, A. 2010. Determining critical period of weed crop competition in faba bean (Vicia faba). International Journal of Agriculture and Biology, 12:318-320.

Khan, I.G., Hassan, M.I., khan and Khan, I.A. 2004. Efficacy of some new herbicidal molecules on grassy and broadleaf weeds in wheat-II. Pakistan Journal of Weed Science Research, 10(1-2):33-38.

Kolhe, S.S. 2001. Integrated weed management in onion (Allium cepa L.). Indian Journal of Weed Science, 33(1\&2):26-29.

Majnoun Hosseini, N. 2008. Grains production. JIHAD Publication Institute, Tehran, Iran.

Mengesha Kebede, Sharma, J.J., Tamado Tana, and Lisanework Nigatu. 2012. Influence of Weed Dynamics on the Productivity of Common Bean (Phaseolus vulgaris L.) in Eastern Ethiopia. East African Journal of Weed Sciences, 7(2):109-120.

Mirshekari Bahram and Reza Siyami. 1999. Relationship between Bean Crop Productivity and Weed Appearance. Department of Agronomy and Plant Breeding, Tabriz Branch, Islamic Azad University, Tabriz, IRAN.

Mondal, D.C., Hossain, A. and Duray, B. 2005. Chemical control in onion (Allium cepa L.) under lateritic belt of West Bengal. Indian Journal of Weed Science, 37:281-282. 